\title{
Tanah Liek Batik's Industry in West Sumatra (a Study of Development Problems)
}

\author{
Rose Rahmidani $^{1}$, Armiati $^{2}$ and Dessi Susanti ${ }^{3}$ \\ ${ }^{1}$ Unversitas Negeri Padang, Indonesia, e-mail: rose_rahmidani@fe.unp.ac.id \\ ${ }^{2}$ Unversitas Negeri Padang, Indonesia, e-mail: armiati@fe.unp.ac.id \\ ${ }^{3}$ Unversitas Negeri Padang, Indonesia, e-mail: dessisusanti@fe.unp.ac.id
}

\begin{abstract}
This study aims to identify the problems faced by the Batik Tanah Liek industry in West Sumatra thus, based on this identification can be found a solution to solve the problem. The research method used is a qualitative method. The study was conducted in three locations, namely Dharmasraya District, South Coastal District and Padang City. Data collection was done by observation, and in-depth interviews. Data analysis techniques were carried out using qualitative analysis. The results showed that the problems faced by the Tanah Liek batik industry in West Sumatra were: expensive product prices, lack of promotion and marketing, difficulty obtaining additional capital, less strategic business locations, sources of raw materials from outside the island, difficulty in getting competent employees, support from the local government has not been maximized, business management has not been good, the marketing area is still limited, and quality is still inferior compared to batik from Java. Based on the description of the problems faced by batik Tanah Liek creative industry in West Sumatra, the alternative form or solution that can be done is; providing business capital assistance, providing training in promotion and marketing techniques, providing financial report writing training, providing trademark and copyright management training, providing business management training, providing production training for workers, and promoting batik Tanah Liek to all West Sumatran and outsiders West Sumatra.
\end{abstract}

Keywords: creative industry, Tanah Liek batik, problems

\section{Introduction}

The creative industry in Indonesia has a big role in economic development because it has been predicted giving GDP contribution reaching Rp.990.4 trillion in 2017. This amount has increased from 2016 as amount Rp. 894.6 trillion to be up from Rp.852 trillion in 2015 (Armiati, 2018). Creative industries are also known as cultural industries defined as industries that have authenticity in individual creativity, skills and talents that have the potential to generate income and create jobs through intellectual property exploitation (Mavis Yi-Ching Chen, Yung Shui Wang, Vicky Sun, 2012; Flew, T., \& Cunningham, S, 2010; Flew, T., 2010).

Based on the data above, it can be interpreted that the contribution of the creative industry has proven to be a support for the national economy. The batik industry is one of the industries included in the creative industry group that is recognized and designated as one of Indonesia's cultural heritage sites. Batik in the context of plurality of Indonesia is almost owned by all ethnicities including; Solo batik, Pekalongan batik, Yogyakarta batik, Lasem batik, Banyuwangi batik, Cirebon batik, Medan batik, Tanah Liek batik (Padang), Sasambo (NTT), Kalimantan batik and so on (Borshalina, T., 2015; Helia, R., Farida, N., \& Prabawani, B., 2015; Rakhmawati, Y., 2016).

The rise of batik users in Indonesia shows that there is an increasing tendency of consumers' preference for batik which has led to the increasing number of batik producers or industries in Indonesia. With the desire of consumers to buy batik clothing shows the business performance of batik is said to be good. The competitive condition of the batik industry is getting tighter, this is shown by the existence of 563 batik industries spread throughout Indonesia. But in fact, in general, the batik industry is currently facing problems including competition for similar batik textile products illegally imported from China. The illegal import value of these batik products reached Rp.290 
billion, and illegally imported batik was cheaper than domestic batik because of unpaid duties (Gatut, B., \& Aryanto, V., 2010).

Batik is not just a cloth but a work of art with special treatment, starting from how to choose the raw material to how to care (Shifrin, Laurie J., 2003). All this time batik has been attached as part of the culture in some areas such as Solo, Yogyakarta, Pekalongan (Rakhmawati, Y., 2016). Evidently, Indonesian batik motifs are more diverse than those known so far. No exception in West Sumatra, it also has a wealth of cultural sites in the form of batik. Batik products produced by West Sumatra have peculiarities ranging from the reproduction of motifs, colors and production processes. West Sumatra batik is known by the name of batik liek. Named Tanah Liek batik which means clay batik. This is because night candles are used to create batik using clay materials. Batik is one part of the creative industry of the handicraft sub-sector.

Tanah Liek batik has a distinctive shape and color that is the color that resembles the color of the liek soil which is brown. Tanah Liek batik cloth is very meaningful to the Minangkabau community until now. This can be seen from the many parents who own and wear the cloth, even though the shape is worn and shabby. Tanah Liek batik is also still used by traditional leaders in Minangkabau as traditional clothing equipment such as Penghulu and Bundo kanduang. As the name implies, Tanah Liek batik uses as the main ingredient for coloring, in addition to other coloring materials.

The process of making batik Tanah Liek is not much different from batik in Java in general. Batik tabah liek batik has its own characteristics, both color and color. As time goes by, the Tanah Liek batik is not only used for traditional events or traditional clothing leaders in Minangkabau, but also used as a business that has selling value and is used by anyone and even used as souvenirs or memento. Therefore, there were changes or reforms both in terms of motif design and in terms of color.

Based on search in several selling locations Tanah Liek batik in West Sumatra, it is known that the price of Tanah Liek batik cloth is in the expensive category. So that the buyers of the Tanah Liek batik cloth are mostly from the upper middle class. The number of business networks in the Batik industry is still limited. Even so far, there is no original batik cloth is sold on the general market. Tanah Liek batik only can be found at the Tanah Liek batik galleries. For West Sumatra, the number of galleries is still small. Based on the data that the authors get on the initial observation, there are only 7 galleries that sell Tanah Liek batik spread in 3 centers of the Tanah Liek batik industry namely Padang City, South Pesisir District and Dharmasraya District

For now, Tanah Liek Batik is less competitive and does not yet have strong competitiveness. The less competitive Tanah Liek batik can be proven from several exhibitions that have been followed, where the number of visitors and buyers is relatively low compared to another regional batik. The promotional media used by the Tanah Liek batik craftsmen are still limited. The limited media promotion that is carried out has caused the land of Tanah Liek batik to be not widely known by the public. Even the indigenous people of Minangkabau themselves were not too familiar with Batik Tanah Liek which was actually a characteristic of the Minangkabau region. The brand image of Tanah Liek batik is still far below Solo batik, Jogja Batik and Pekalongan Batik. Promotions made by craftsmen, in general, are limited to participating in batik exhibitions in several places if there is an invitation. This condition naturally results in the difficulty of the Tanah Liek batik industry to develop because of the problems it faces.

From the phenomena faced by Tanah Liek batik industry, it is necessary to conduct an in-depth study to find a solution to the problem so that Tanah Liek batik can develop. Therefore, it needs to be identified more deeply, what is the problem for Tanah Liek batik industry, so that based on the results of this identification a solution to the problem can be sought.

Researches on creative industry topics have been very much done by other researchers from various countries. Research conducted by Oakley explains the importance of the role of the creative industry in economic development in the UK and explains the various problems faced by creative industries in the UK (Oakley, 2004). Liang's research describes the obstacles faced by creative industries in 
Indonesia, such as human resources, distribution channels, local company preferences and agency, regulation and funding (Liang, 2013). However, there have been no studies conducted to find out the problems faced by the creative industry of liek soil batik in West Sumatra.

Based on the background description and previous research studies, it is known that there has been no research that specifically addresses the problems faced by the creative industries of Tanah Liek batik in West Sumatra. Therefore, the aim of this research is to find out and at the same time provide an alternative solution to the problems faced by the liek batik industry in West Sumatra. To support the achievement of this goal, qualitative descriptive research methods are used in the hope that this method can address the problem of this research.

Small Industry. According to BPS, (CBS: Central Bureau of Statistic), small industries are industries that use labor between 5 and 19 people. The Ministry of Industry and Trade defines a small industry as an industrial business activity that has an investment value of up to Rp. 200,000,000, excluding land and business premises (Decree of the Minister of Industry and Trade Number 254/MPP/Kep/ 1997). The cooperative department classifies small entrepreneurs based on criteria, namely business turnover of not more than 2,000,000,000, - and wealth (not including land and buildings) not more than Rp. 600,000,000,- (Rejekiningsih, T. W., 2004).

Generally, the small and medium business sector has characteristics; a) Bookkeeping systems are relatively simple and tend not to follow standard accounting administration rules. Sometimes bookkeeping is not up to date, so it is difficult to assess the performance of its business; b) The business margin tends to be thin considering the very high competition; c) Limited capital; d) Managerial experience in managing the company is still very limited; e) Economic scale is too small, so it is difficult to expect to be able to reduce costs to reach long-term efficiency points; f) Marketing and negotiation capabilities and market diversification are very limited; g) The ability to obtain funding from the capital market is low, given the limitations in the administrative system. To get funds from the capital market, a company must follow a standard administrative system and must be transparent.

A business contains potential benefits and costs. For many people, an important benefit is a personal satisfaction gained from operating its own business. Business owners can use all of their capabilities and can use them freely, also can gain power through the operation of their own business. Other benefits obtained are financial benefits. Compared to large businesses, small businesses have several potential and comparative advantages, as stated by Anoraga (2002) including a) Small businesses operate spread throughout all corners of various business fields. This is because most small businesses arise to meet the demand (aggregate demand) that occurs in the regional area. It could be that the orientation of small business products is not limited to product orientation but has reached the level of consumer orientation. For this, a managerial decision is needed that requires high foresight. With the spread of small businesses, the problem of urbanization and the rural-urban gap can be minimized. At least reduce the concentration of the intensity of employment in certain regions which will have the effect of urbanization and other social problems; b) Small businesses operate with fixed capital investment in fixed assets at a low level. Most of the capital is absorbed in working capital needs. Because what is at stake is small, the implications of small businesses have high freedom to enter or exit the market. Thus, production activities can be stopped at any time, if the economic conditions faced are not profitable. Another consequence of the low value of fixed assets is that it is easy to up to date the product. As a result, it will have a high degree of immunity to international economic turmoil; c) Some small businesses can be said to be labor intensive due to the use of simple technology. The percentage of value-added distribution in labor is relatively large. Thus, income distribution can be achieved more. In addition, the advantages of small businesses are that there is a close relationship between the owner and employees, which makes it difficult to terminate employment (termination of employment). This situation shows how small businesses have socioeconomic functions. 
The weaknesses that are owned by small businesses according to Anoraga (2002) consist of: a) The marketing scale is local, if it is not done by the company itself through the marketing area. This clearly cannot accelerate progressive sales quickly; b) The personal involvement in the company generally revolves around kinship or brotherhood or also because of familiar social relations; c) Is an "one man show" that is one person has many functions that are generally carried out by the owner of the company, starting from basic bookkeeping to disbursement of funds; d) Weak system of recording, based on memory only so that it is not documented; e) Planning only with simple calculations and analysis, with principles around profit that can be reached quickly, without convolution and shortterm orientation; f) Often in relation to planning, it focuses on personal or family interests only. So that the owner does not know the loss or profit of the company because there are no clear boundaries that belong to the company and personal; g) Weak promotion and marketing of its products; h) Decision making is often done by feeling and not based on rational thoughts and concepts.

Batik Industry Development. The batik industry in Indonesia is generally a small and medium-sized industry (SME) which is the livelihood of some people (Ismail, T., 2012; Nurainun, N., 2013; Setyorini, 2013). Before the monetary crisis in 1997 this small and medium-sized industry had experienced rapid progress. Some batik entrepreneurs had experienced a heyday. Especially in the 1980s batik was the official dress that had to be worn at every state event or another official event. So that it can introduce and enhance the image of batik in the international world at that time.

The batik industry in Indonesia is spread in several regions on the Java island which later became the name of the types of batik such as Pekalongan batik, Surakarta batik, Yogya batik, Lasem batik, Cirebon batik, Sragen batik. Every batik from the area has a specific motif characteristic. There are three types of batik produced, namely batik, stamp batik and batik printing. The development of the batik industry in Indonesia is closely related to the development of batik which began since hundreds of years ago (Nurainun, 2013).

This batik industry has become a significant contributor to the Indonesian economy; therefore, the government needs to pay attention to the development of this industry. Development is an effort to increase thinking maturity coupled with better change. Thus, development can also be interpreted as a change that is planned in the desired direction (Ridwan, M., \& Hatuwe, M., 2017). There are four aspects contained in the development, namely: 1) Giving emphasis to capacity (capacity), namely efforts to increase capacity and energy needed, 2) Emphasis on equity aspects in order to avoid division in society that can destroy its capacity, 3) Providing greater power and authority to the community. With the intention that the results of development can really benefit the community because the aspirations and participation of the community towards development can increase. In addition to the authority to make corrections to decisions made about resource locations, 4) Development implies the continuity of development that must be considered given the limited resources available (Ridwan, M., \& Hatuwe, M., 2017).

Batik art is the art of drawing on cloth for clothing which became one of the family cultures of ancient Indonesian kings (Ulum 2016; 14). If referred to its historical development, the history of batik in Indonesia has been so long and cannot be separated from the history of kings and sultanates on the island of Java. It can be said that the center of the distribution of batik in Indonesia originated from the island of Java, including the area of West Sumatra.

The history of art and batik industry in West Sumatra then only emerged in the third period, namely in the Dutch period. At that time, West Sumatra was in the atmosphere of the Dutch blockade, including the trade blockade. The Dutch also stopped the supply of batik cloth from Java. Since the time before World War I, according to Susanto (2010) West Sumatra was a consumer area of batik, especially batik produced by Pekalongan, Solo and Yogyakarta. According to him, because of the Dutch blockade, the batik trade in this area became suspended, so a number of batik traders who usually got batik supplies from Java did not have stock to trade. With such conditions, finally, a number of traders began to produce their own batik. Furthermore, according to Susanto, the 
characteristics of batik from Padang are mostly black, yellow and red purple with the patterns of Banyumasan, Indramayuan, Solo, and Yogyakarta.

Basically, the batik industry in West Sumatra has not been able to become " the host in his own house". This means that market demand is actually far greater than existing products, and market demand is not met by local production. Most of the West Sumatra batik needs are still supplied from Java. Besides being of slightly better quality, these Javanese batik products are easy to get. Ironic indeed, there are batik motifs and patterns made in West Sumatra, because they cannot be fulfilled according to the craftsmen at the expected time, finally, the ordering is forced to place orders at centers production in Java (Herwandi, 2016).

Batik is one of the characteristics of Indonesian culture. Especially since the recognition of Indonesian batik as the "Intangible World Heritage" on October 2, 2009 by the United Nations Educational, Scientific and Cultural Organization (UNESCO) and has comparative advantages in the economic field, which is expected to improve the welfare of the people that. This means that batik has gained international recognition as one of Indonesia's cultural eyes, so that it is expected to motivate and elevate the dignity of batik craftsmen and support efforts to improve people's welfare (Nurhidayat, 2010: 15; Hauser-Schäublin, B., 2011; Ismail, T., 2012)

As the emergence of batik in Indonesia, it turns out West Sumatra also has its own history of batik. It was only around 1994 that the existence of Minang realm batik was known. Batik is called liek batik or clay batik. Although until now there is no literature that can ascertain the origin of liek soil batik in West Sumatra, at least the information from people who claim to store this type of batik, can be a reinforcement of the existence of liek batik. The origin of this batik was thought to be from China which allegedly entered Minangkabau in the 16th century during the Minangkabau Kingdom centered in Pagaruyung, Batusangkar. Clay batik was lost without a trace during the Japanese occupation, but this batik technique was reintroduced in 1994. Clay batik received an award from the United Nations Educational, Scientific and Cultural Organization (UNESCO) as the Master of the Oral and Intangible Heritage of Humanity since in October 2009. Batik was not only known as a tradition from Java, but also found as a product of Minangkabau culture (West Sumatra) (Herwandi, 2016).

The motifs commonly developed for liek batik are seahorse, hong, and a number of Chinese motifs. Currently reintroduced the Minangkabau tradition motifs such as the siriah motif in carano, kaluak paku, kuciang lalok, patuang kayu, taring plate, and fan. Furthermore, new motifs of inspiration arose based on the wealth of Minangkabau cultures such as tabuik, jam gadang and rumah gadang. New motifs also emerged that were created from natural wealth such as the motif of the oil palm taserak in Dharmasraya, the motives of marine plants and animals in the South Coast. The Innovation of motifs made by each gallery of batik liek batik varies and depends on ideas that are influenced by local wisdom. To make the motives that consumers are interested in, the ideas outlined must be explained philosophically by craftsmen. It aims that batik in the Minang region has characteristics that cannot be compared to another batik outside West Sumatra (Steelyana, W., 2012; Arssad, M., Jupriani, MS, \& Erwin, MS, 2015; Herwandi, 2016; Antoni , MV, 2017).

\section{Research Methodology}

The research method used is a qualitative method. The qualitative method is using because the problems are complex and meaningful. In addition, researchers intend to understand social situations in depth, find patterns, hypotheses and theories related to the focus of the problem.

This research was conducted in three locations in the province of West Sumatra. The choice of this location is done because the Tanah Liek batik industry is very potential in the effort to develop the creative economy and preserve the Minangkabau cultural heritage. Based on data from the Department of Cooperatives, Industry and Trade of West Sumatra Province (2016), the business unit of Tanah Liek batik craft industry in West Sumatra is spread across 3 centers of Tanah Liek batik making in Dharmasraya district, South Pesisir District and Padang City. Data collection is done by observation and in-depth interviews. Data analysis techniques were carried out using qualitative 
analysis of the Miles \& Huberman (2007) model which suggested for data analysis in qualitative research was carried out continuously and interactively until complete so that the data was saturated. Activities in data analysis are data reduction, data display and conclusion drawing/verification. To ensure the validity of the research data, an examination of the validity and reliability of the data was carried out.

\section{Result and Discussion}

Especially in the area of West Sumatra, the art and batik industry has begun to grow. Although West Sumatra batik production is still many and quite advanced, in fact, the art and batik industry has not been well developed (Herwandi 2016), because when compared it will be far less than batik in Java (Wulandari 2011: 39). The motifs that are commonly developed for Tanah Liek batik are sea horse motifs, hong birds, and a number of Chinese motifs. Currently reintroduced the motifs of the Minangkbau tradition such as the Syrian motif in carano, kaluak paku, kuciang lalok, patuang kayu, dance plates, fans. Furthermore, several new motifs inspired by Minanagkabau cultural wealth are also used such as tabuik, jam gadang, rumah gadang and other new motifs.

The results of the research conducted on 7 businesses of the liek batik industry in West Sumatra precisely in the liek batik industry in Padang City, Dharmasraya District and South Pesisir district showed specific data about this industry. The following is presented the profile of Tanah Liek soil batik industry, which is the respondent in this study, as follows:

Table 1. Business Profile of Tanah Liek Batik industry in West Sumatra

\begin{tabular}{|c|c|c|c|}
\hline $\begin{array}{c}\text { No } \\
.\end{array}$ & $\begin{array}{l}\text { Business Name / } \\
\text { Year Standing }\end{array}$ & Owner Name & Address \\
\hline 1. & $\begin{array}{l}\text { Citra Monalisa Tanah } \\
\text { Liek Batik } \\
\text { - Year standing } 1995 \\
\end{array}$ & Hj. Wirda Hanim & $\begin{array}{l}\text { Sawahan Dalam Street No. } 33 \\
\text { Padang, Sumatera Barat }\end{array}$ \\
\hline 2. & $\begin{array}{l}\text { Bundo Kanduang } \\
\text { Tanah Liek Batik } \\
\text { - Year standing } 2016 \\
\end{array}$ & M.Iqbal/ Nora Basrida & $\begin{array}{l}\text { Ratulangi Street No. } 5 \\
\text { Padang, Sumatera Barat }\end{array}$ \\
\hline 3. & $\begin{array}{l}\text { Ayesha Collection } \\
\text { - Year standing } 2009\end{array}$ & Fitria Lusia & $\begin{array}{l}\text { Andam Dewi Street No. } 8 \\
\text { Marapalam, Padang, Sumatera } \\
\text { Barat }\end{array}$ \\
\hline 4. & $\begin{array}{l}\text { Fitria Endika Tanah } \\
\text { Liek batik } \\
\text { - Year standing } 2014\end{array}$ & H. Syahburdin & $\begin{array}{l}\text { Aru Street No. } 8 \text { Lubuk Begalung } \\
\text { Padang, Sumatera Barat }\end{array}$ \\
\hline 5. & $\begin{array}{l}\text { Pondok Batik } \\
\text { - Year standing } 2013\end{array}$ & Nurcholis & $\begin{array}{l}\text { Jorong Padang Sari, Bukit } \\
\text { Mindawa } \\
\text { Dharmasraya, Sumatera Barat }\end{array}$ \\
\hline 6. & $\begin{array}{l}\text { Citra Mandiri } \\
\text { - Year standing } 2000\end{array}$ & Eni Mulatni & $\begin{array}{l}\text { Jorong Teluk Sikai, Blok B } \\
\text { Sitiung I } \\
\text { Dharmasraya, Sumatera Barat }\end{array}$ \\
\hline 7. & $\begin{array}{l}\text { Dewi Busana } \\
\text { - Year standing } 2013 \\
\end{array}$ & Dewi Hapsari & $\begin{array}{l}\text { Nagari Lubuk Bonta, Silaut I } \\
\text { Pesisir Selatan, Sumatera Barat }\end{array}$ \\
\hline
\end{tabular}

Source : Processed primary data, 2017

In Padang city, there are 4 (four) respondents who are entrepreneurs in Tanah Liek batik industry located in Padang Timur sub-district, Padang Barat sub-district and Lubuk Begalung sub-district. Research respondents who were the perpetrators of the Tanah Liek batik industry in Dharmasraya Regency totaled 2 (two) people from Jorong Padang Sari, Bukit Mindawa and Jorong Teluk Sikai, 
Sitiung I. While respondents from Pesisir Selatan Regency were only one businessman in the land batik industry liek from Silaut Subdistrict.

Furthermore, from the results of this study also identified the problems faced by business actors of Creative industries of Tanah Liek batik in West Sumatra. The problems identified are as follows: 1) Expensive price of products, 2) Promotion and marketing, 3) Difficulty obtaining additional capital, 4) Less strategic business locations, 5) Sources of raw materials from outside the island, 6) Difficult to get competent employees, 7) Support from local government is not optimal, 8) Bad business management, 9) Marketing area is still limited, and 10) Quality is still inferior to batik from Java. Basically, the batik industry in West Sumatra has not been able to become a "host at his own house". This means that market demand is greater than existing products, and market demand is not met by local production. Most of the West Sumatra batik needs are still supplied from Java. Besides the rather better quality, the batik from Java is easy to get. Ironically, there are batik motifs and patterns made in West Sumatra, because they cannot be fulfilled according to the craftsmen at the expected time, finally, the ordering is forced to place an order to the production centers in Java.

The expensive price problem of Tanah Liek batik product, one of which is from the raw material used for coloring. One of the uniqueness of Tanah Liek batik is the coloring materials used come from natural colors such as clay, jengkol skin (Pithecellobium NETNIA), mangosteen (Garcinia mangostana), gum gambir (Unicaria gambir), rice straw (Oryza sativa), mahogany skin (Screktenia mahogany), rambutan skin (Nephelium lappeceum) and plants traditionally used for coloring. The use of natural color is more closely related to the art element so that the target is to be consumed by the upper middle class and abroad, therefore, the selling price is higher (Lestari, 2001; Borshalina, T, 2015).). The use of natural dyes in some countries is still believed to be safer than synthetic dyes because of their non-carcinogenic properties, relatively simple manufacturing and use technology. This is very suitable for small and medium industries which are currently being promoted by the government to support export commodities. The development of natural dyes for Indonesia which is a tropical region is very potential because of the types of plants that can produce dyes. In the process of production and use of natural dyes, clean and environmentally friendly (Sutara, P. K., 2009).

Generally, it can be said that West Sumatra lacks the power and human resources of batik craftsmen. The regions that have other inter-batik industry centers are Padang City, Dharmasraya District, and South Pesisir District. The craftsmen have uneven skills. Those who can work from the beginning to the end make batik countable on the fingers (only a few). Some are only capable of patterning, some can just slam, some are coloring. Rarely can master the whole. A competent workforce is one factor that greatly influences the course of a business (David, H., \& Dorn, D., 2013; Deming, D. J., 2017). Based on the description of the problems faced by Tanah Liek batik creative industry in West Sumatra, it can be a concern for the government to overcome these problems. The forms of business or activities that can be carried out are; 1) giving business capital assistance, 2) holding training in promotion and marketing techniques, 3) giving financial report writing training, 4) giving brand management and copyright training, 5) giving business management training, 6) giving production training for workers, and 7) promoting Tanah Liek batik to all people of West Sumatra and outside West Sumatra.

\section{Conclusion}

This research was conducted on 7 creative industries of Tanah Liek batik in West Sumatra in Padang City, Dharmasraya District and Pesisir Selatan District. In general, identified problems faced by each business are 1) Expensive price of products, 2) Promotion and marketing, 3) Difficulty obtaining additional capital, 4) Business location is less strategic, 5) Sources of raw materials from outside the island, 6) Difficult to get competent employees, 7) Support from local government is not maximal, 8) Business management is not good, 9) Marketing area is still limited, and 10) Quality is still inferior to batik from Java. 
References

Anoraga, Pandji. 2002. Koperasi, Kewirausahaan Dan Usaha Kecil, Penerbit. Rineka Cipta, Jakarta. Goelt.

Antoni, M. V. 2017. Motif Minang Kaluak Paku Kacang Balimbiang pada Busana Kasual (Doctoral dissertation, Institut Seni Indonesia Yogyakarta).

Armiati, Rose Rahmidani, Dessi Susanti. 2010. The Study Of Creative Industry Fashion Condition In The West Sumatra, Based On Issues It Faces. Proceeding.

Arssad, M., Jupriani, M. S., \& Erwin, M. S. 2015. Studi Tentang Desain Motif Dan Teknik Batik Tanah Liek Di Sanggar Citra Monalisa Sawahan Padang. Serupa The Journal of Art Education, $3(2)$.

Borshalina, T. 2015. Marketing strategy and the development of Batik Trusmi in the regency of Cirebon which used natural coloring matters. Procedia-Social and Behavioral Sciences, 169, 217-226.

David, H., \& Dorn, D. 2013. The growth of low-skill service jobs and the polarization of the US labor market. American Economic Review, 103(5), 1553-97.

Deming, D. J. 2017. The growing importance of social skills in the labor market. The Quarterly Journal of Economics, 132(4), 1593-1640.

Flew, T. 2010. Toward a cultural economic geography of creative industries and urban development: introduction to the special issue on creative industries and urban development. The information society, 26(2), 85-91.

Flew, T., \& Cunningham, S. 2010. Creative industries after the first decade of debate. The information society, 26(2), 113-123.

Gatut, B., \& Aryanto, V. 2010. Batik Industry Of Indonesia: The Rise, Fall And Prospects. Studies in Business \& Economics, 5(3).

Hauser-Schäublin, B. 2011. Preah Vihear. From object of colonial desire to a contested World Heritage site. World Heritage Angkor and Beyond. Circumstances and Implications of UNESCO Listings in Cambodia. Hauser-Schäublin, Brigitta, ed, 33-56.

Helia, R., Farida, N., \& Prabawani, B. 2015. Pengaruh Orientasi Pasar dan Orientasi Kewirausahaan Terhadap Keunggulan Bersaing Melalui Inovasi Produk sebagai Variabel Antara (Studi Kasus pada IKM Batik di Kampung Batik Laweyan, Solo). Jurnal Ilmu Administrasi Bisnis, 4(4), 281290.

Herwandi. 2016. Industri Batik di Sumatera Barat (Perspektif Sejarah): Kebutuhan Pasar Besar Namun Kemampuan Produksi Kecil1.

Ismail, T. 2012. The development of entrepreneurial social competence and business network to improve competitive advantage and business performance of small medium sized enterprises: a case study of batik industry in Indonesia. Procedia-Social and Behavioral Sciences, 65, 4651.

Mavis Yi-Ching Chen, Yung Shui Wang, Vicky Sun. 2012. "Intellectual capital and organizational commitment: Evidence from cultural creative industries in Taiwan", Personnel Review, Vol. 41 Iss: 3 pp. $321-339$.

Meriastuti, E. E. 2018. Penataan Kampung Batik Pecinan Babagan Lasem sebagai Pusaka Kota (Doctoral dissertation, Universitas Muhammadiyah Surakarta).

Miles, Mattew B dan A. Michael Huberman. 2007. Analisis Data Kulitatif Buku Sumber Tentang Metode-Metode Baru. Jakarta: iniversitas indonesia press.

Nugroho, P. S., Cahyadin, M., Perindustrian, D., Kebudayaan, D., \& Pariwisata, D. K. 2010. Analisis Perkembangan Industri Kreatif Di Indonesia. Simposium Ekonomi Indonesia Pasca Krisis Ekonomi Global, Surabaya.

Nurainun, N. 2013. Analisis industri batik di Indonesia. Fokus Ekonomi, 7(3).

Rakhmawati, Y. 2016. Batik Madura: Heritage Cyberbranding. Jurnal Komunikasi, 10(1), 57-65. 
Rejekiningsih, T. W. 2004. Mengukur Besarnya Peranan Industri Kecil dalam Perekonomian di Propinsi Jawa Tengah. Jurnal Dinamika Pembangunan (JDP), 1(Nomor 2), 125-136.

Ridwan, M., \& Hatuwe, M. 2017. Pembinaan Industri Kecil dan Menengah Pada Dinas Perindustrian, Perdagangan, Koperasi dan UMKM Kota Bontang. Jurnal Administrative Reform (JAR), 2(2), 187-199.

Setyorini, C. T., Pinasti, M., \& Rokhayati, H. 2013. Strengthening the internal factors of batik cluster smes in indonesia: A case of six districts in south-central java. International Journal of Business, Humanities and Technology, 3(1), 21-28.

Shifrin, Laurie J. 2003. Batiks And Beyond.The Patchwork Place. Martingale Company.

Sjaifudian, H., \& Chotim, E. E. 1994. Dimensi strategis pengembangan usaha kecil: subkontrak pada industri garmen batik. Akatiga.

Soesanti, I., \& Syahputra, R. 2016. Batik Production Process Optimization Using Particle Swarm Optimization Method. Journal of Theoretical and Applied Information Technology, 86(2), 272.

Steelyana, W. 2012. Batik, A Beautiful Cultural Heritage That Preserve Culture And Support Economic Development In Indonesia.

Sutara, P. K. 2009. Jenis Tumbuhan Sebagai Pewarna Alam Pada Beberapa Perusahan Tenun Di Gianyar. Bumi Lestari, 9(2), 217-223. 